\author{
Daniel LICHOŃ ${ }^{1}$ \\ Anna MIKOLAJCZYK ${ }^{2}$ \\ Lukasz KISZKOWIAK ${ }^{3}$ \\ Tomasz LĄCKI ${ }^{4}$
}

\title{
IDENTIFICATION OF UAV STATIC AERODYNAMIC CHARACTERISTICS IN THE WATER TUNNEL BALANCE RESEARCH
}

\begin{abstract}
This work presents the identification of static aerodynamic characteristics in the water tunnel experiments. The tested object was a scale model of unmanned aerial vehicle (UAV) target drone OCP-Jet. The research was performed in the water tunnel Rolling Hills Research Corporation model no. 2436, Military University of Technology, Warsaw. Water tunnel experiments allow to perform static and dynamic balance measurements, dye flow visualizations and PIV flow field measurements. The advantage of the use of the water tunnel are relatively inexpensive researches and the possibility to use small models manufactured with 3D printing technology. However, testing the flying objects in the water medium has limitations due to difficulties in satisfying the flow similarity criteria. In this paper the researches were focused on identification of the static aerodynamic characteristics with the use of balance measurements. The forces and moments characteristics were performed. The experimental results were compared with full scale aircraft characteristics, calculated with analytical methods and vortex lattice method.
\end{abstract}

Keywords: static aerodynamics characteristics, water tunnel, UAV, balance measurements, aerodynamics forces, aerodynamics moments

\section{Introduction}

Static aerodynamic characteristics includes important information about aerodynamic forces and moments acting on the aircraft in steady state flight condition. Determining of static characteristics is a key issue for the estimation of flying qualities such as flight performance, static stability and manoeuvrability. Therefore, the identification of static aerodynamics characteristics is a matter

\footnotetext{
1 Autor do korespondencji/corresponding author: Daniel Lichoń, Rzeszow University of Technology, tel.: (+48) 17743 2346, e-mail: d_lichon@prz.edu.pl

2 Anna Mikołajczyk, Military University of Technology, e-mail: anna.mikolajczyk@wat.edu.pl

${ }^{3}$ Łukasz Kiszkowiak, Military University of Technology, e-mail: 1kiszkowiak@wat.edu.pl

4 Tomasz Łącki, Military University of Technology, e-mail: tomasz.lacki@wat.edu.pl
} 
of experimental researches and numerical analysis. The tunnel researches and flight tests are used in the identification of aerodynamic characteristics and flight performance. Water tunnel measurement is a one of experimental methods in the aircraft research programme. The available publications [1-4] indicate the following advantages of water tunnel tests:

- researchers are relatively inexpensive,

- simplicity of manufacturing and modifying the test model with the use of 3D printing technology,

- static and dynamic balance measurements of forces and moments supported by three axial model manipulator,

- dye flow visualization,

- flow field measurements with PIV technology.

On the other hand there exist some limitations in researches of flying objects in water tunnel. Physical properties of water medium such as density, viscosity and compressibility are significantly different than in air medium case. It is problematic to satisfy flow similarity criteria. The Reynolds number achieved on models in the water tunnel is approximately two or three rows lower than for full scale airplane [1]. However, for micro aerial vehicles it is possible to meet Reynolds number criterion. The sound velocity in water is four times higher than in the air medium. Thus it is impossible to satisfy Mach number in researches [1].

In this work the balance measurements of static aerodynamic characteristics were performed. The research object was 1:8 scale model of UAV flying drone OCP-Jet [9]. The force (lift, drag and side) and moment (pitching, rolling and yawing) characteristics were measured. In order to verify the usefulness of experimental results the characteristics were calculated for full scale airplane. The calculation included analytical methods [10] and vortex lattice method with the use of "Tornado" software $[11,12]$. The collected data was discussed in order to evaluate the usefulness and a range of use the water tunnel in the identification of the flying object characteristics.

\section{Research facilities}

The research was performed in the water tunnel Rolling Hills Research Corporation (RHRC) Model no. 2436 (fig. 1). The test section (fig. 1, item 7) is equipped with model support (fig. 1, item 8) that provides the rotational movement along three axes. The measurement system includes five component strain balance (fig. 2), flow velocity meter and computer control unit. The strain balance is mounted inside the model and connects the model with manipulator support. The visualisation system consists of 6 independent dye tanks. The dye is distributed into the model airframe nozzles or external mobile nozzle. Additionally 2-dimensional PIV measurement are performed. 


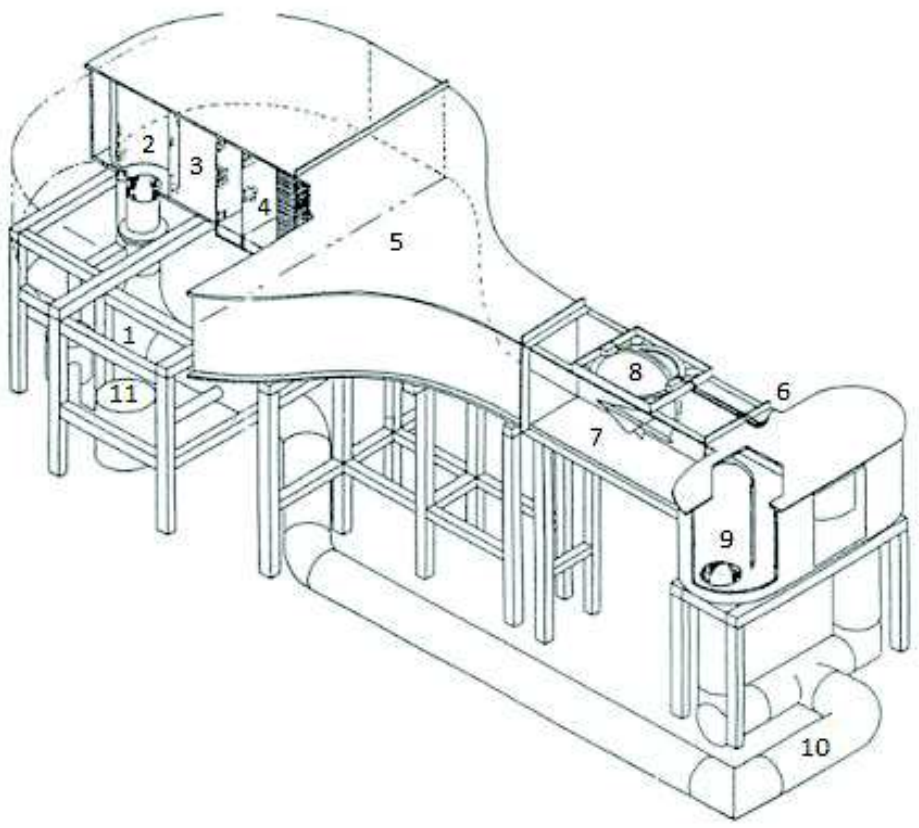

Fig. 1. RHRC 2436 water tunnel layout: 1 - pump, 2 - perforated inlet, 3 - delivery plenum, 4 flow conditioning elements, 5 - contraction section, 6 - dye lines, 7 - test section, 8 - model support, 9 - discharge plenum, 10 - return piping, 11 - filter system

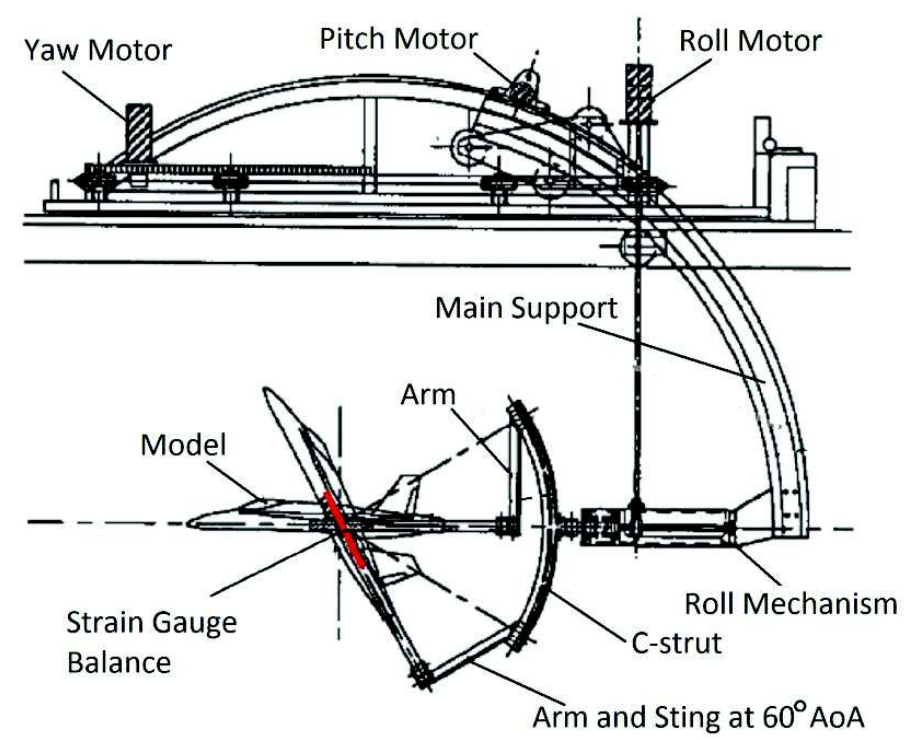

Fig. 2. Model manipulator (up) and strain balance (down) scheme 
Table 1. Specifications of RHRC 2436 water tunnel, model support manipulator and strain balance

\begin{tabular}{|c|c|}
\hline \multicolumn{2}{|r|}{ Water tunnel } \\
\hline Overall dimensions & $6.1 \mathrm{mx} 2.5 \mathrm{mx} 12.2 \mathrm{~m}$ \\
\hline Water capacity & $18 \mathrm{~m}^{3}$ \\
\hline Flow velocity & $0-0.3 \mathrm{~m}$ \\
\hline Test section dimensions & $0.6 \mathrm{~m} \times 0.9 \mathrm{~m} \times 1.8 \mathrm{~m}$ \\
\hline Turbulence intensity & $<1.0 \%$ RMS \\
\hline Water pomp motor & 7.5 KM 230V AC 3-phase $60 \mathrm{~Hz} 30 \mathrm{~A}$ \\
\hline \multicolumn{2}{|r|}{ Model support manipulator } \\
\hline Type of movements & Three axes rotation \\
\hline Pitch; yaw; roll angle $(\min / \max )$ & $-10^{\circ} / 36^{\circ} ;-25^{\circ} / 25^{\circ} ;-520^{\circ} / 520^{\circ}$ \\
\hline Pitch; yaw; roll rate (max) & $15\left[\operatorname{deg} \cdot \mathrm{s}^{-1}\right] ; 15\left[\operatorname{deg} \cdot \mathrm{s}^{-1}\right] ; 40\left[\operatorname{deg} \cdot \mathrm{s}^{-1}\right]$ \\
\hline Pitch; yaw; roll acceleration (max) & $5\left[\mathrm{deg} \cdot \mathrm{s}^{-2}\right] ; 2\left[\mathrm{deg} \cdot \mathrm{s}^{-2}\right] ; 2\left[\mathrm{deg} \cdot \mathrm{s}^{-1}\right]$ \\
\hline \multicolumn{2}{|r|}{ Strain balance } \\
\hline Measured values & $\begin{array}{l}\text { Normal }(\mathrm{N}) \text { and side }(\mathrm{Y}) \text { forces, pitching }(\mathrm{PM}) \text {, yawing } \\
(\mathrm{YM}) \text { and rolling }(\mathrm{RM}) \text { moments }\end{array}$ \\
\hline Size (diameter $\mathrm{x}$ length) & $\begin{array}{l}0.75 \text { in } \times 3.75 \text { in (without waterproof cover and mount } \\
\text { adapters) }\end{array}$ \\
\hline Number of channels (sections) & Total $=5(2 \mathrm{x}$ PM, 2x YM, 1x RM) \\
\hline $\begin{array}{l}\text { Type of strain gage } \\
\text { (for each section) }\end{array}$ & $\begin{array}{l}4 \times 1000 \Omega \text { semi-conductor gauge arranged in full Wheat- } \\
\text { stone bridge }\end{array}$ \\
\hline $\begin{array}{ll}\text { Maximum } & \text { loading } \\
\text { Pitch/yaw/torque } & \\
\end{array}$ & $15 \mathrm{in} \cdot \mathrm{lb} / 4 \mathrm{in} \cdot \mathrm{lb} / 2.5 \mathrm{in} \cdot \mathrm{lb}$ \\
\hline
\end{tabular}

\section{Test model}

The tested object is target drone OCP-Jet (MSP Company). For the research the 1:8 scale model was manufactured with the use of rapid prototyping technology. The article contains necessary technical data, for the full specification see [9]. Note that scaled model has modified aft fuselage part (fig. 3ab). The balance is mounted inside the model and must be inserted through the widen circular cross section.

Table 2. Specifications of OCP-Jet tested model (selected technical data)

\begin{tabular}{|l|c|c|}
\hline \multicolumn{1}{|c|}{ Name } & Full scale OCP-Jet & Research model (1:8 scale) \\
\hline Wing span, $\mathrm{mm}$ & 2855 & 356.9 \\
\hline Wing area, $\mathrm{cm}^{2}$ & 13500 & 210.94 \\
\hline Planform area* $\mathrm{cm}^{2}$ & 22440 & 350.63 \\
\hline MAC, $\mathrm{mm}$ & 459.2 & 57.4 \\
\hline Length, $\mathrm{mm}$ & 3555 & 444.4 \\
\hline Height, $\mathrm{mm}$ & 820 & 102.5 \\
\hline Reference point & $25 \% \mathrm{MAC}$ & $25 \% \mathrm{MAC}$ \\
\hline
\end{tabular}

* Airplane top view overall area 
b)
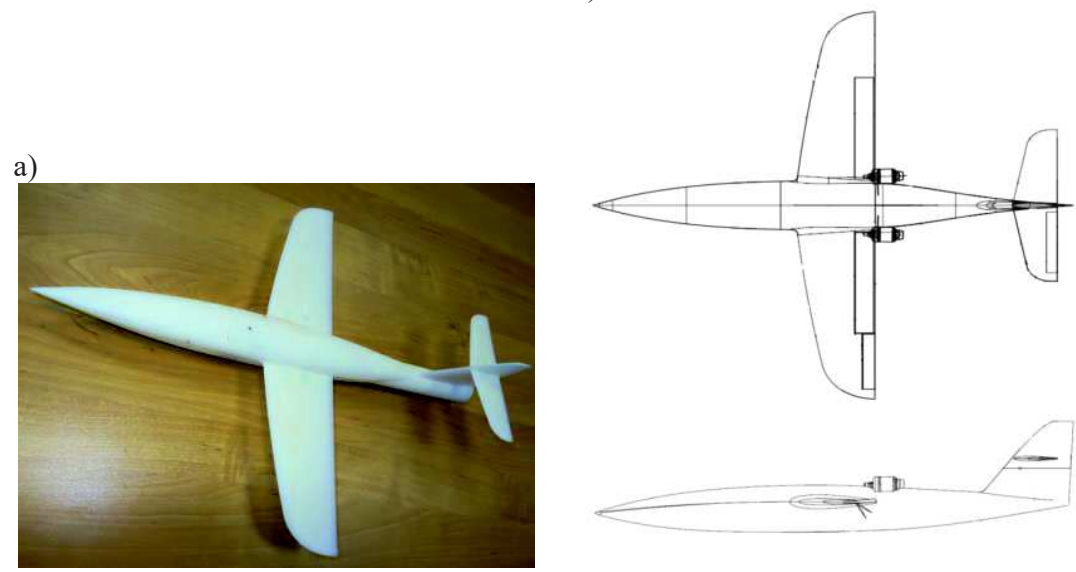

Fig. 3. View (a) and drawing (b) OCP-Jet tested model

The experiment consists of preparing the model, where the model is mounted and levelled along the flow direction in the test section. Considering the sensitivity of balance sensors the next step relies on balance tare in order to eliminate negative effect of model buoyant and weight force. After stabilizing the flow velocity (exact to a $0.02 \mathrm{in} / \mathrm{s}$ ) the final measurement of hydrodynamic forces and moments is performed.

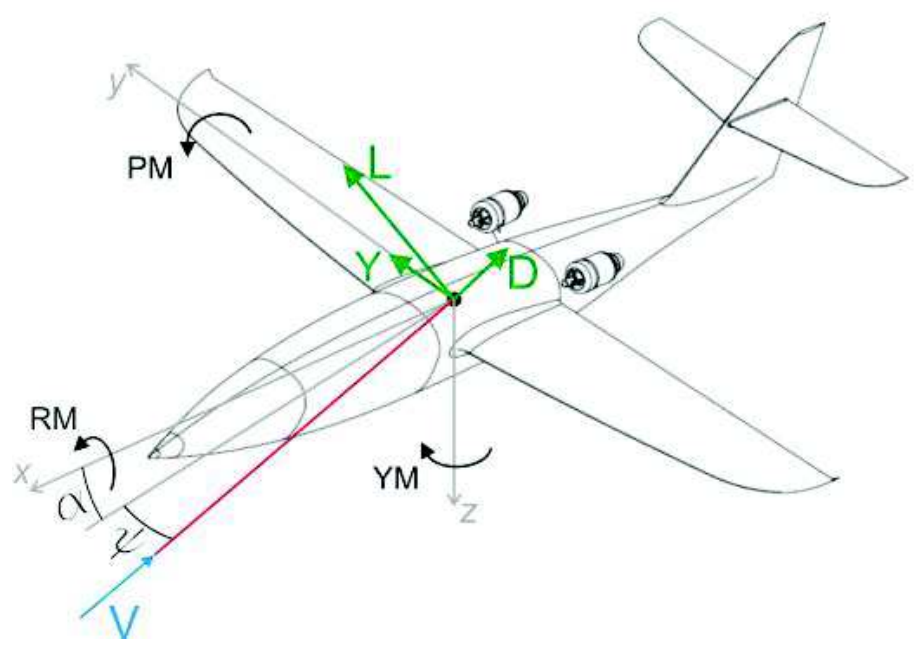

Fig. 4. Components of measured forces and moments

The model was tested with the angle of attack sequence (from $\alpha=0^{\circ}$ to $\alpha=$ $\left.34^{\circ}, \Delta \alpha=2^{\circ}\right)$ in three configurations of yaw angle $\left(\psi=0^{\circ}, 10^{\circ}, 20^{\circ}\right)$. Water flow velocity was set to $\mathrm{V}=0.3 \mathrm{~m} / \mathrm{s}$. The components of hydrodynamic 
force (lift, drag, side) and hydrodynamic moment (pitch, roll, yaw) were measured. Results are shown as a characteristics of forces and moments (in imperial units) and its coefficients due to the angle of attack. This is common form of flying object.

\section{Discussion}

The main problem of usefulness of experimental results is the fact that the model of flying object was tested in water medium. There are significant differences between properties of air and water. The density and kinematic viscosity of water are suitably $\rho_{\text {water }}=999.1 \mathrm{~kg} / \mathrm{m}^{3}$ and $\nu_{\text {water }}=1.142 \cdot 10^{-6} \mathrm{~m}^{2} / \mathrm{s}$ while the air parameters are $\rho_{\text {air }}=1.225 \mathrm{~kg} / \mathrm{m}^{3}$ and $\nu_{\text {air }}=1.45 \cdot 10^{-5} \mathrm{~m}^{2} / \mathrm{s}$. Thus Reynolds number was different in the model and in the full scale object and equals suitably: $\operatorname{Re}_{\text {model, }} \mathrm{V}=0.3 \mathrm{~m} / \mathrm{s}=1.2 \cdot 10^{4}$ and $\mathrm{Re}_{\text {object, } \mathrm{V}=75 \mathrm{~m} / \mathrm{s}}=2.4 \cdot 10^{6}$. The experimental data characteristics was compared with the full scale aircraft characteristics. The classical method [10] and "Tornado" vortex lattice method (VLM) software $[11,12]$ were used to obtain full scale airplane characteristics.

The measured force characteristics (figs. 5 to 8 ) has expected run for airplane case. It can be clearly seen that in the practical angle of attack (AoA) range the lift characteristics $C_{L}(\alpha)$ is linear. Drag characteristics $C_{D}(\alpha)$ and polar $C_{L}\left(C_{D}\right)$ exhibit square dependency due to induced drag influence.

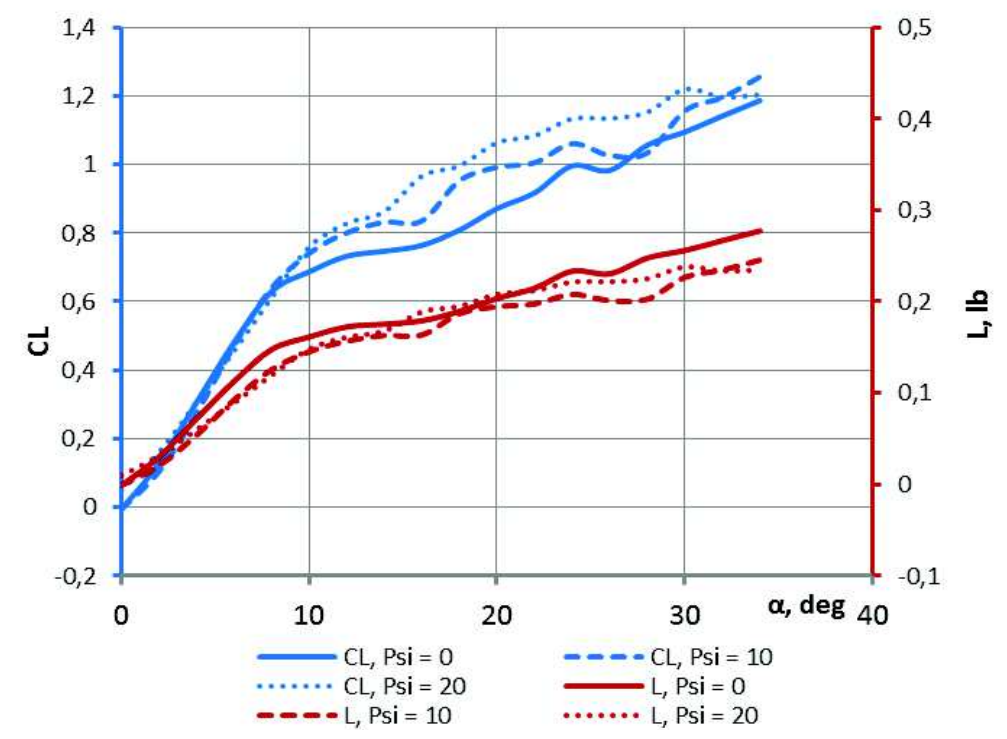

Fig. 5. Lift force characteristics 


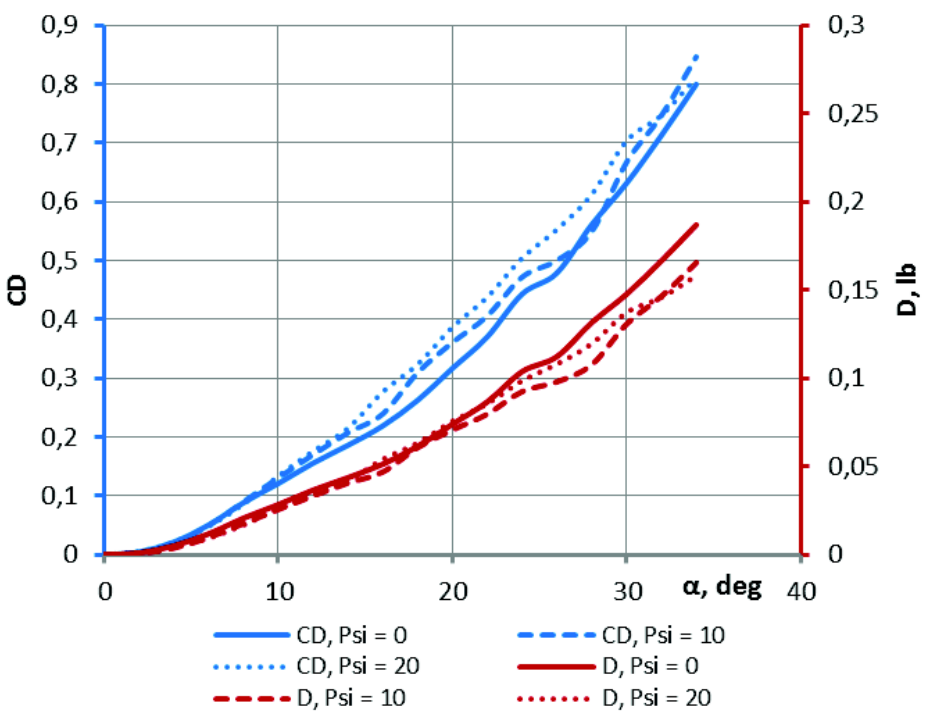

Fig. 6. Drag force characteristics

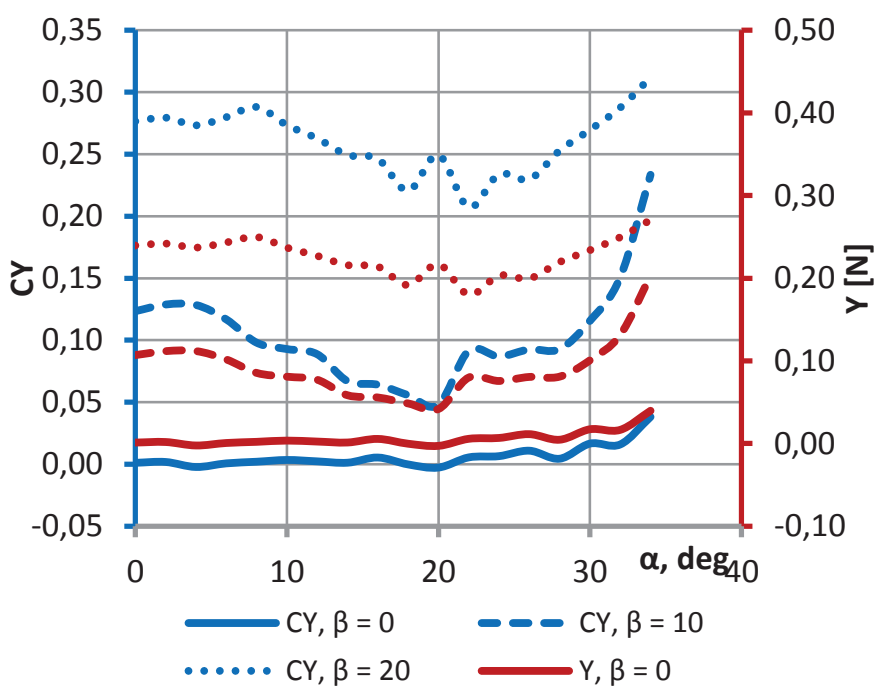

Fig. 7. Side force characteristics

Furthermore, the $\mathrm{C}_{\mathrm{L}}(\alpha)$ characteristics obtained with analytical methods and VLM method (fig. 15) in the linear range has virtually the same run. The lift curve slope is $\frac{d C_{L}}{d \alpha}=4.35$ for experimental and analytical results and $\frac{d C_{L}}{d \alpha}=4.87$ for VLM method. The difference for VLM method is caused by the lack of fuselage body influence on the main wing (VLM software [12] does not consider the 
body, see fig. 18). In the range above linear dependence of lift curve slope it can be seen that water tunnel characteristics shows corrugated increment of lift coefficient without a stall point. The interpretation is that the water tunnel balance measures only the normal force that is separated geometrically on lift and drag component. Therefore, on higher AoA the normal force increases due to increasing model planform area crosswise the flow direction (fig. 2).

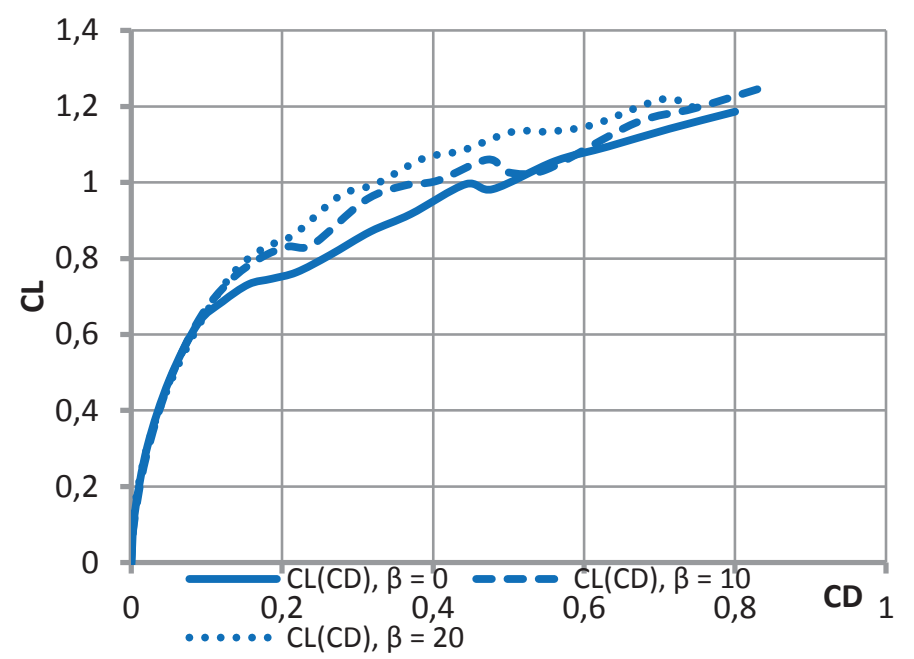

Fig. 8. Force coefficient polar

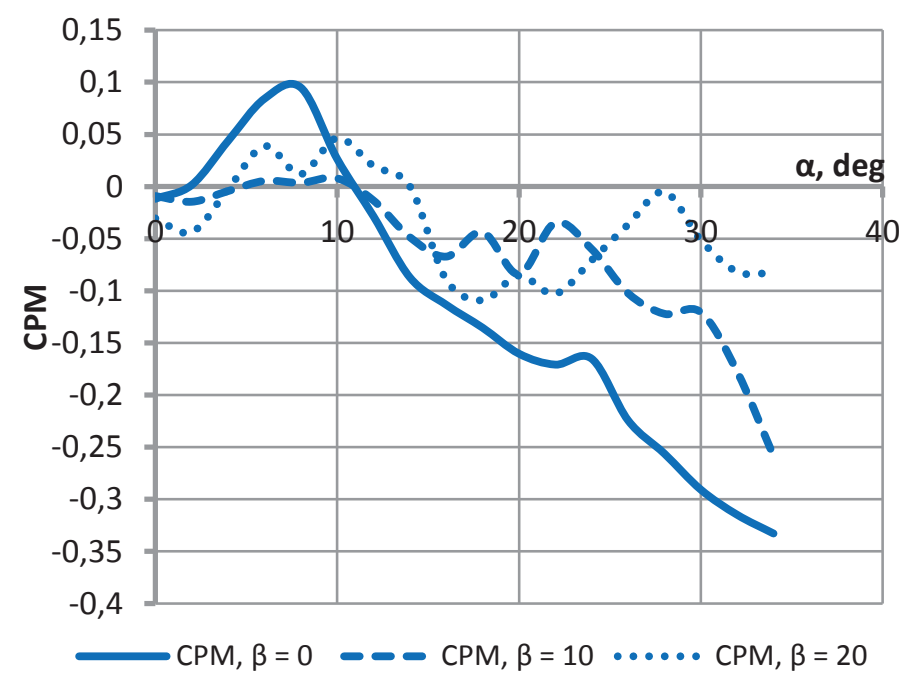

Fig. 9. Pitching moment coefficient characteristics 


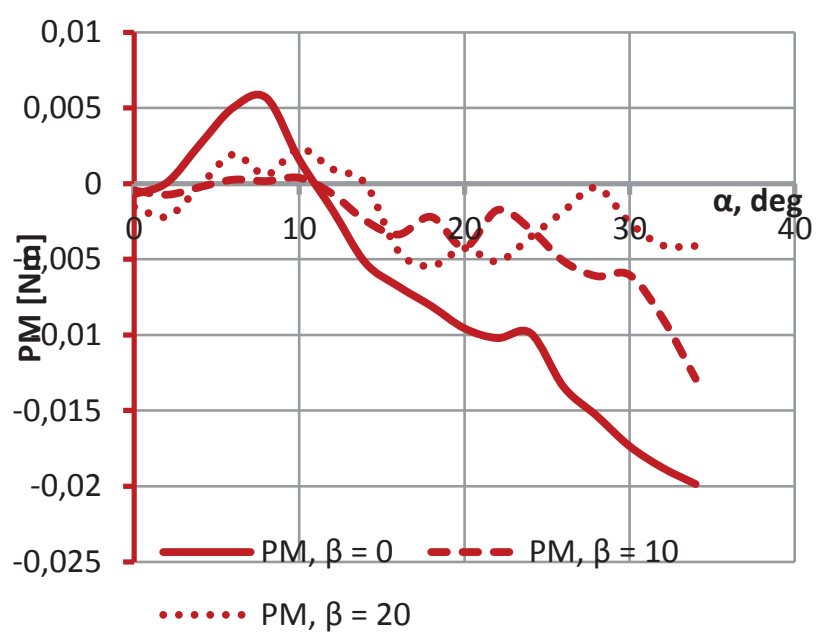

Fig. 10. Pitching moment characteristics

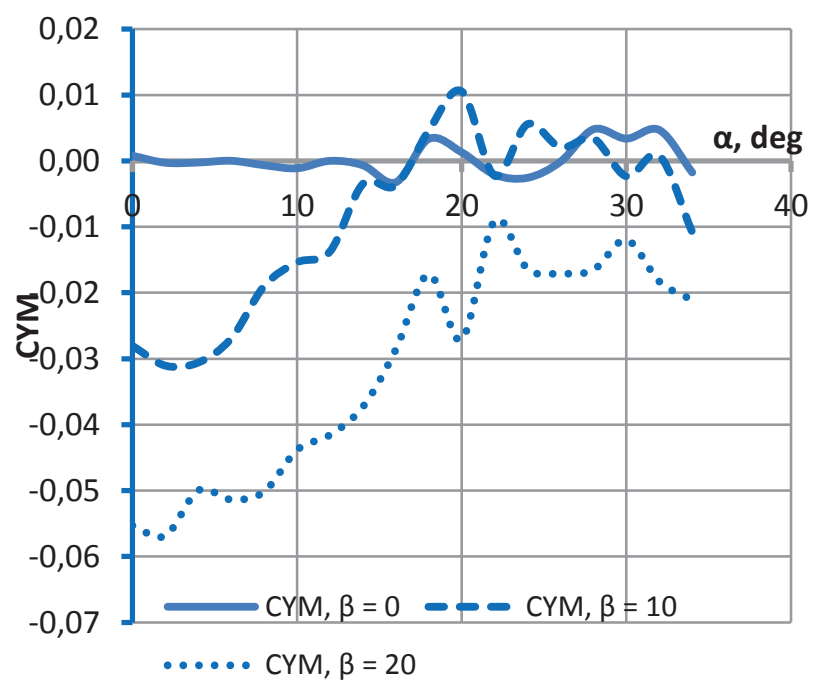

Fig. 11. Yawing moment coefficient characteristics

In a case of drag coefficient characteristics there is significant discrepancy between experiment and other methods. Considering the characteristics $C_{L}^{2}=$ $f\left(C_{D}\right)$ (fig. 16) it can be seen that the static derivative in linear range of $C_{\mathrm{L}}(\alpha)$ dependence equals $\frac{d C_{L}^{2}}{d C_{D}}=4.33$ for experimental results while for other methods the average value is $\frac{d C_{L}^{2}}{d C_{D}}=17.4$. The probable cause of the difference is the fact that the drag coefficient in the experiment is identified indirectly by geometrical 
separating the normal force on force and drag components. Therefore, increasing model planform area across the flow direction results in increasing measured drag force. As it was expected, experimental moment characteristics displays aerodynamic configuration for aircraft with classical rear tail. The average value of pitching moment coefficient derivative due to AoA remains negative $\frac{d C_{m}}{d \alpha}<$ 0 , that indicates positive longitudinal static stability characteristic (figs. 9, 10).

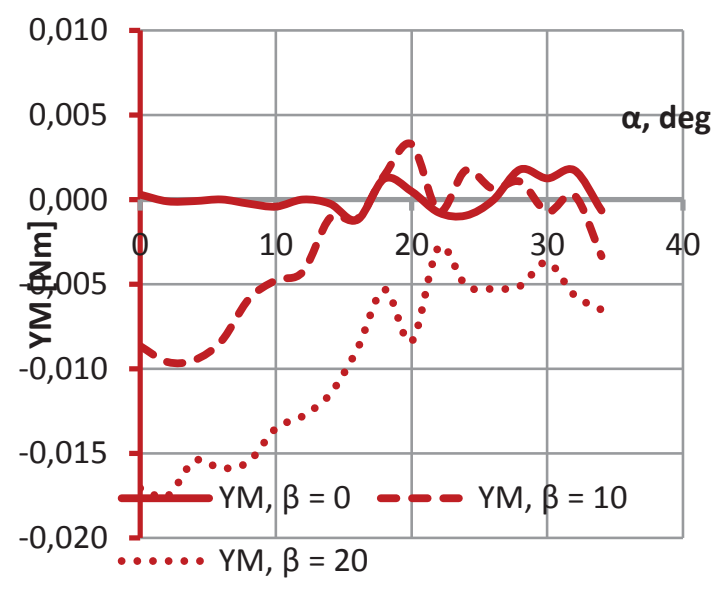

Fig. 12. Yawing moment characteristics

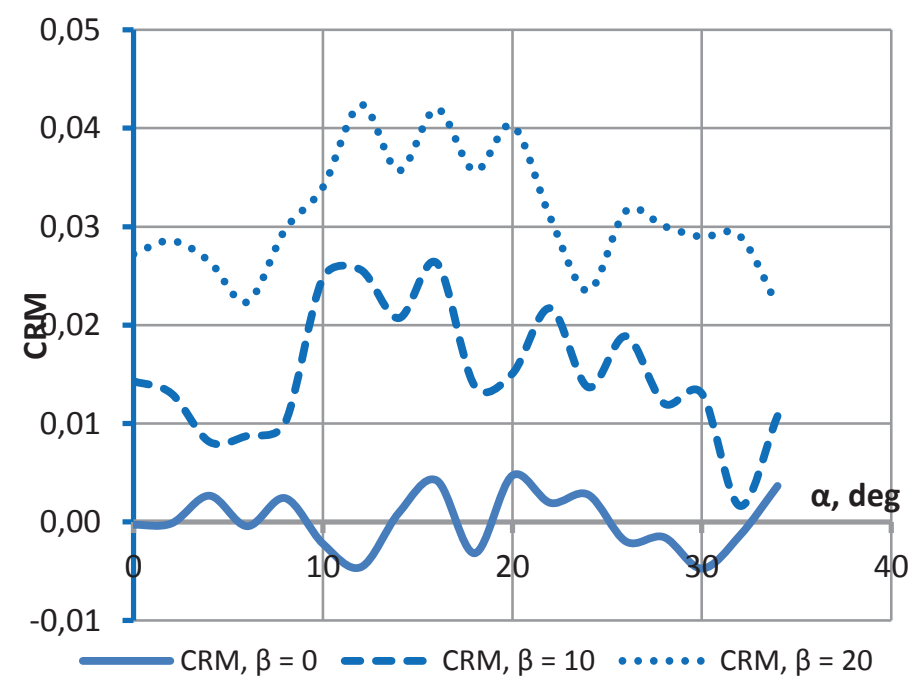

Fig. 13. Rolling moment coefficient characteristics 


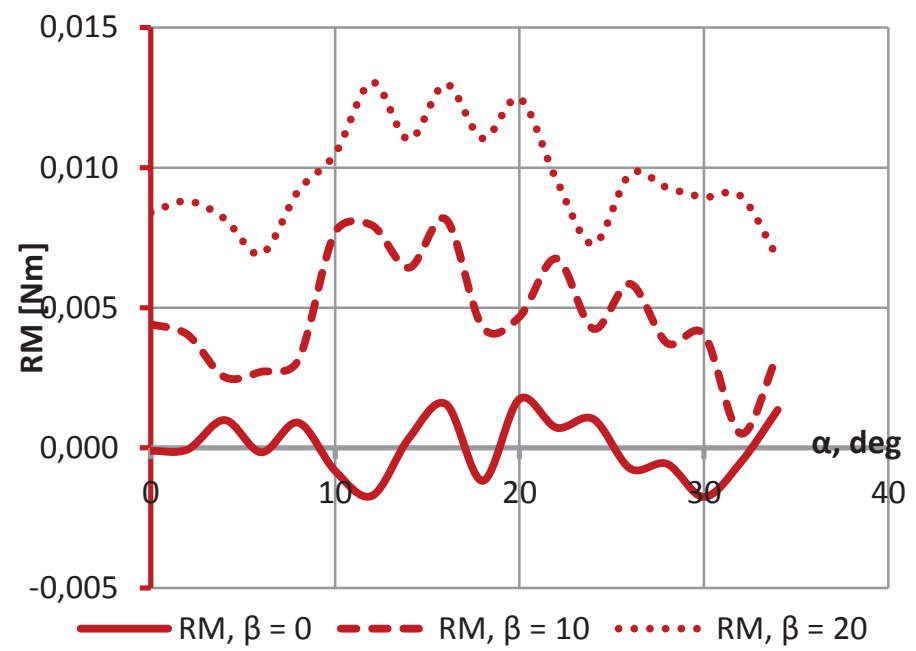

Fig. 14. Rolling moment characteristics

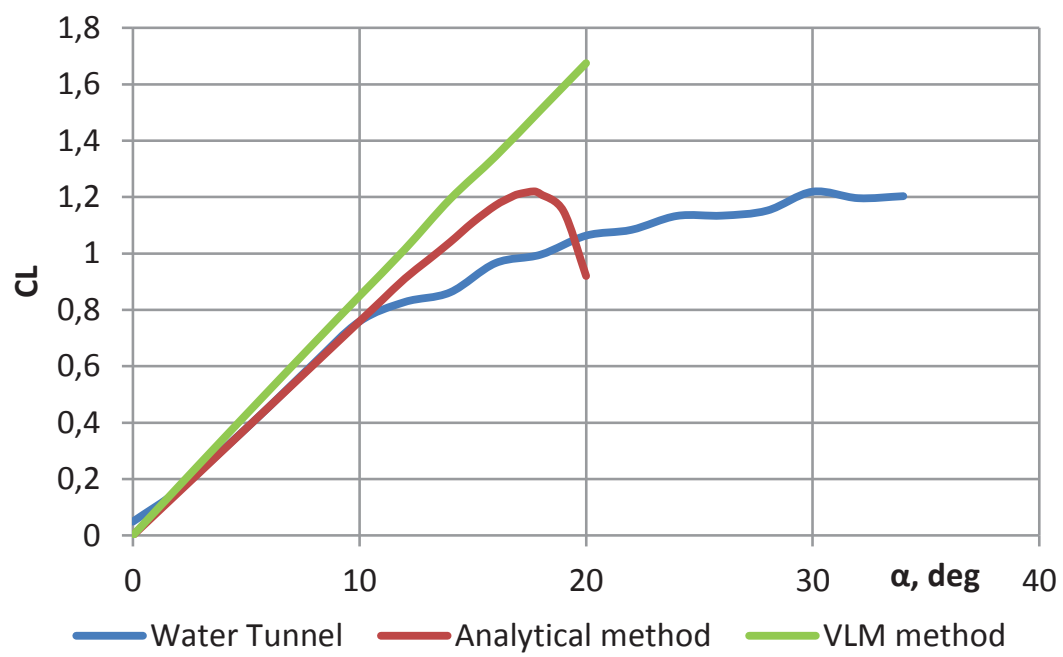

Fig. 15. Comparison of force characteristics $\mathrm{C}_{\mathrm{L}}(\alpha)$

\section{Conclusion}

Comparison of experimental results with calculated characteristics (fig. 17) shows discrepancy between experimental and VLM method results. It is caused by the lack of fuselage body in VLM modelling. In this case the analytical $\mathrm{C}_{\mathrm{m}}(\alpha)$ characteristic for the whole aircraft and wing-tail was shown separately. The analytical characteristics overlap with experimental and VLM runs. The only 
D. Lichoń et al.

problematic part of experimental $\mathrm{C}_{\mathrm{m}}(\alpha)$ run is at AoA less than $\alpha<8^{\circ}$ where $\frac{d C_{m}}{d \alpha}>0$. The probable reason is an influence of the main wing hydrodynamic shadow on the horizontal tail. Rolling and yawing moment characteristics (fig. 11 to 14 ) point that tested aircraft has positive static lateral stability characteristics. The measured values of pitching and rolling coefficients increase with yawing angle increment due to vertical tail influence.

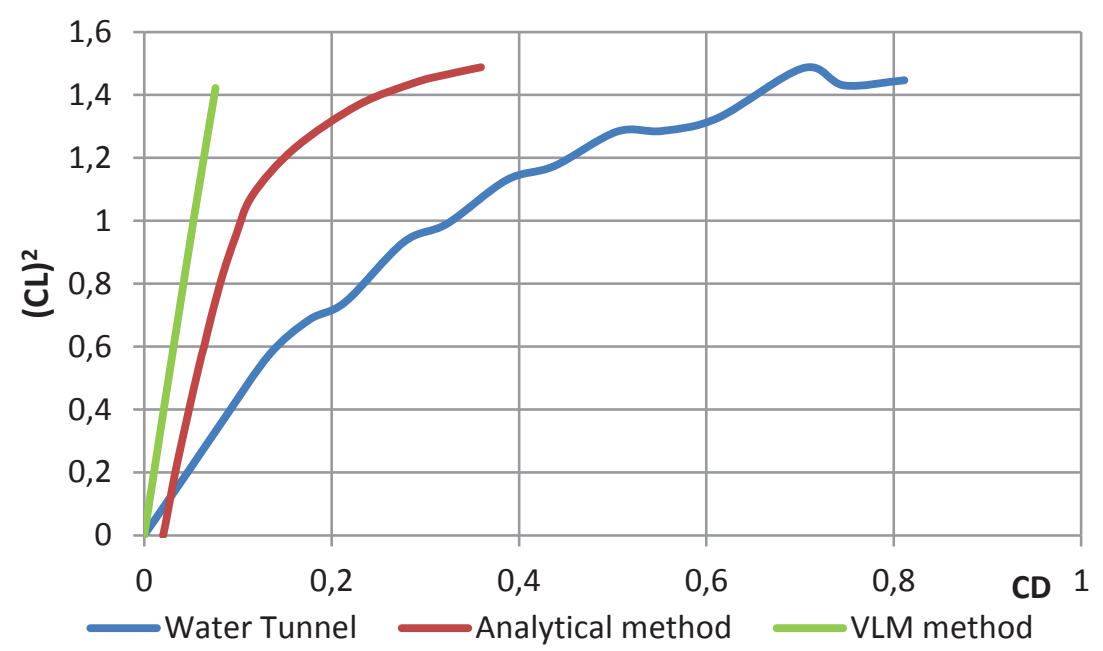

Fig. 16. Comparison of force polar characteristics $C_{L}\left(C_{D}\right)$

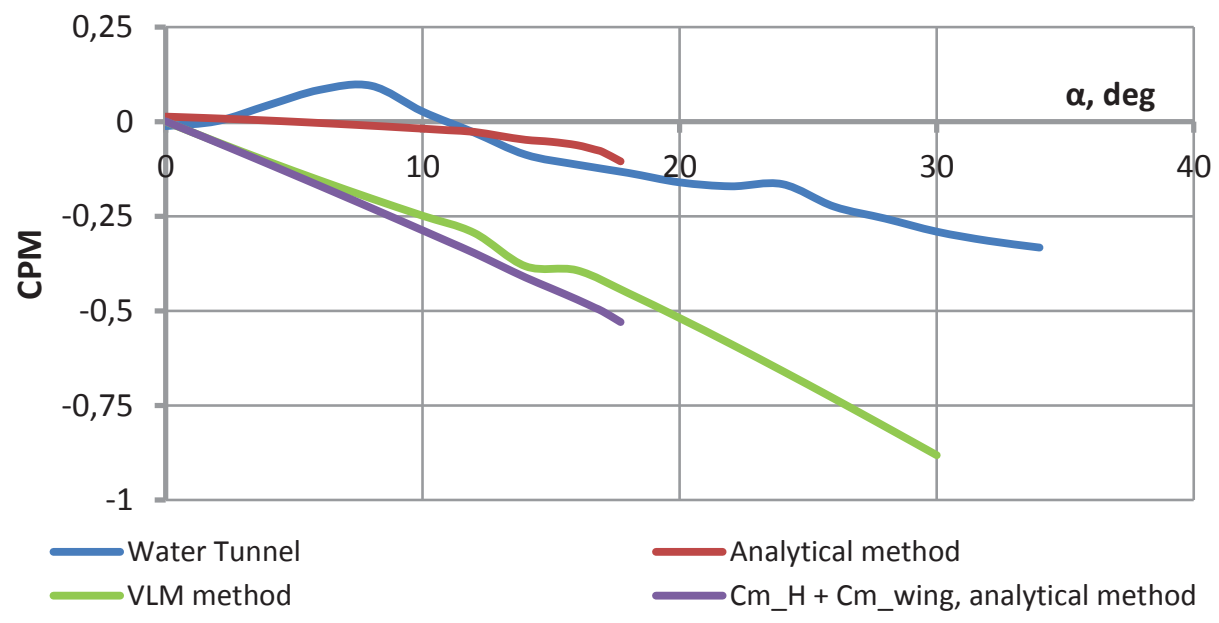

Fig. 17. Comparison of pitching moment characteristics $\mathrm{C}_{\mathrm{PM}}(\alpha)$ 


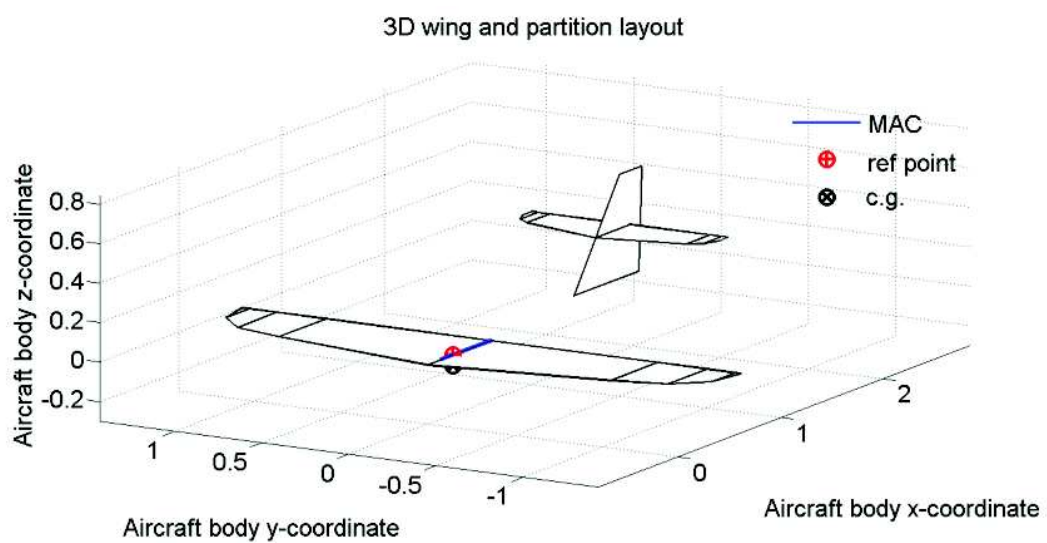

Fig. 18. Tornado VLM full scale model geometry

\section{Acknowledgement}

The article has been written within the confines of training period at The Faculty of Mechatronics and Aeronautical Engineering, Military University of Technology, Warsaw. The researches have been performed with the use of Aircraft Propulsion Laboratory (Laboratorium Badań Napędów Lotniczych) facilities.

\section{References}

[1] Erm L. P., Ol M.V.: An assessment of the usefulness of water tunnels for aerodynamic investigations, Defence Science and Technology Organization, DSTO-TR2803, Australia, December 2012.

[2] Erm L. P., Ferrarotto P.: Development of a five-component strain-gauge balance for the DSTO water tunnel, Defence Science and Technology Organization, DSTOTR-0597, Australia, November 2009.

[3] Erm L. P.: Development and use of a dynamic-testing capability for the DSTO water tunnel, Defence Science and Technology Organization, DSTO-TR-1836, Australia, March 2006.

[4] Erm L. P.: Measurement of flow-induced pressures on the surface of a model in a flow visualization water tunnel, Experiments in Fluids, 35 (2003), 533-540.

[5] Jaroszewicz A., Stachów J., et al.: Water tunel experimental studies of leading edge vortex control on delta wing MAV, $49^{\text {th }}$ AIAA Aerospace Sciences Meeting, AIAA 2011-1158, Orlando, January 2011.

[6] Czekałowski P., Sibilski K., Szczepański C.: Wpływ zredukowanej częstotliwości trzepotania skrzydła entomoptera na obciążenia aerodynamiczne - wizualizacja opływu skrzydla oraz pomiary sił aerodynamicznych, Modelowanie Inżynierskie, 41 (2011), 27-37.

[7] Mueller T. J.: Aerodynamic measurements at low Reynolds numbers for fixed wing micro-air vehicles, Development and operation of UAVs for military and civil applications, Belgium, 1999.

[8] http://www.rollinghillsresearch.com 
[9] http://www.uav.com.pl

[10] Fiszdon W.: Mechanika lotu, PWN, Warszawa, 1961.

[11] Melin T.: A vortex lattice Matlab implementation for linerar aerodynamic wing applications, Royal Institute of Technology, Sweden, 2000.

[12] Melin T.: Tornado VLM software, tornado.redhammer.se

\section{IDENTYFIKACJA STATYCZNYCH CHARAKTERYSTYK AERODYNAMICZNYCH SAMOLOTU KLASY BAL Z WYKORZYSTANIEM POMIARÓW WAGOWYCH W TUNELU WODNYM}

\section{Streszczenie}

W niniejszej pracy przeprowadzono eksperymentalną analizę zmęczeniową łopatki sprężarki lotniczego silnika turbinowego. Rozkład temperatur na łopatce wykorzystano do określenia długości powstałej w trakcie badań szczeliny zmęczeniowej. Łopatka z karbem symulującym uszkodzenie obcym obiektem została poddana drganiom poprzecznym wstanie rezonansu. Podczas badań zarówno amplituda przemieszczenia wierzchołka ostrza, a także długość pęknięcia były monitorowane. W tym samym czasie wykonano kamerą termowizyjną zdjęcia rozkład temperatury. W pierwszej fazie pracy wykresy amplitudowo-częstotliwościowe uzyskano dla różnej wielkości pęknięć. Określono liczbę cykli obciążeń do inicjacji pęknięć, a także dynamikę wzrostu pęknięć w łopatce sprężarki narażonej na drgania. Dodatkowym efektem pracy jest porównanie długości szczelin zmierzonych bezpośrednio na badanej łopatce jak i na obrazie z rozkładami temperatury wokół pęknięcia. Przedstawiono zalety metody pomiaru długości szczeliny z wykorzystaniem zdjęć z kamery termowizyjnej. Wyniki przedstawione w niniejszym artykule mają wartość teoretyczną i praktyczną.

Słowa kluczowe: statyczne charakterystyki aerodynamiczne, tunel wodny, BAL, pomiary wagowe, siły aerodynamiczne, momenty aerodynamiczne

DOI: $10.7862 / \mathrm{rm} .2016 .11$

Otrzymano/received: $10.04 .2016 r$.

Zaakceptowano/accepted: 14.06.2016 r. 